\title{
Zika Outbreak Associated Neurological Syndromes in Jamaica
}

\author{
M Williams ${ }^{1,2}$, A Ali $^{1,2}$
}

\begin{abstract}
Objective: To describe the demographic, clinical and laboratory features and, treatment and outcomes of Zika outbreak associated neurological syndromes.

Methods: Zika outbreak associated neurological syndromes refer to specific neurological syndromes characterized by acute or sub-acute monophasic bilateral areflexic or hyporeflexic limb weakness and/or sensory impairment with or without cranial nerve, meningeal, myelopathic or encephalopathic abnormalities, with or without antecedent viral symptoms and without a more reasonable explanation during the Zika outbreak April to September 2016 at the Kingston Public Hospital (KPH). Medical records of men and women aged 12 years and over meeting these criteria were identified from intra-hospital records and reviewed for specific neurological syndrome classification based on clinical features, cerebrospinal fluid analysis, brain and spinal cord magnetic resonance imaging and neurophysiology.

Results: Thirty-five cases were identified and 25 medical records reviewed. Three, eleven and seven patients met Brighton diagnostic criteria for Guillain-Barre syndrome (GBS) levels 1, 2 and 3, respectively. Other neurological syndromes were transverse myelitis (1), meningoencephalitis (2) and acute disseminated encephalomyelitis or [ADEM] (1). These four patients had additional findings typical of Guillain-Barre syndrome. Twenty-one reported antecedent viral symptoms, 12 required mechanical ventilation for respiratory failure and 23 received Intravenous Immunoglobulin (IVIg). Four of the 25 (16\%) patients died.

Conclusion: The current Zika outbreak in Jamaica has been accompanied by a spectrum of immunologically mediated acute neurological syndromes, the most common of which is GBS and appears associated with significant morbidity and mortality.
\end{abstract}

Keywords: Guillain-Barre syndrome, Jamaica, neurological syndromes, Zika virus

\section{El Brote de Zika aSociado con Síndromes Neurológicos en Jamaica}

M Williams ${ }^{1,2}$, A Ali $^{1,2}$

\begin{abstract}
RESUMEN
Objetivo: Describir la demográfica, características clínicas y de laboratorio, tratamiento y los resultados del brote de Zika asociado con síndromes neurológicos.

Métodos: El brote de Zika asociado con síndromes neurológicos se refiere a síndromes neurológicos específicos, caracterizados por debilidad de las extremidades con hiporreflexia o arreflexia bilateral monofásica aguda o sub-aguda, y/o discapacidad sensorial con o sin anormalidades del nervio craneal, anomalías meníngeas, mielopáticas, o encefalopáticas; con o sin antecedentes de síntomas de virosis, y sin una explicación más razonable durante el brote de Zika de abril a septiembre de 2016 en el Hospital público de Kingston (KPH). Las historias clínicas de hombres y mujeres a partir de los 12 años de edad que satisfacian estos criterios, fueron identificadas en los archivos intrahospitalarios y revisadas para su clasificación con el síndrome neurológico específico a partir de sus características clínicas, el análisis del líquido cefalorraquídeo, del cerebro y la médula espinal, y la neurofisiología.

Resultados: Treinta y cinco casos fueron identificados y 25 historias clínicas revisadas. Tres, once y siete pacientes correspondieron a los criterios diagnósticos de Brighton para los niveles 1, 2, y 3 del síndrome de Guillain-Barre (SGB), respectivamente. Otros síndromes neurológicos fueron la mielitis transversal (1), la meningoencefalitis (2) y la encefalomielitis aguda diseminada ó EAD (1). Estos cuatro
\end{abstract}

From: ${ }^{1}$ Kingston Public Hospital, Kingston, Jamaica and ${ }^{2}$ The University of the West Indies, Kingston 7, Jamaica.
Correspondence: Dr M Williams, Tai Wing, Andrews Memorial Hospital, Kingston, Jamaica, West Indies. Email: mariedm1@yahoo.com 
pacientes tuvieron otros hallazgos típicos del sindrome de Guillain-Barré. Veintiuno reportaron antecedentes de síntomas virales, 12 necesitaron ventilación mecánica a causa de insuficiencia respiratoria, y 23 recibieron inmunoglobulina intravenosa (IgIV). Cuatro de los 25 pacientes (16\%) murieron.

Conclusión: El brote actual de Zika en Jamaica ha ido acompañado de un espectro de síndromes neurológicos agudos mediados inmunológicamente, de los cuales el más común es el SGB, que aparece asociado con una morbilidad y mortalidad significativas.

Palabras claves: Síndrome de Guillain-Barré, Jamaica, síndromes neurológicos, virus del Zika

West Indian Med J 2016; 65 (3): 439

\section{INTRODUCTION}

The association between Zika virus ( $\mathrm{ZikV}$ ) infection and acute neurological disorders such as Guillain-Barre syndrome (GBS) and microcephaly was declared a public health emergency of international concern by the World Health Organization [WHO] (1).

Zika, an arbovirus of the Flaviviridae family, first isolated from a Rhesus monkey obtained from the Zika forest of Uganda in 1947, caused human infections and minor outbreaks characterized by a mild febrile illness first in Uganda and Tanzania in 1952 and then across Africa and Asia $(2,3)$. The 2007 Yap Island outbreak was the first reported Zika outbreak outside Africa and Asia (4). French Polynesia had an increase in GBS during a Zika outbreak which began October 2013; 42 cases in seven months and all were Zika-virus IgM, IgG and/or RNA positive [OR 34.1, $p<0.0001$ ] (5).

Jamaica first reported Zika virus infection in January 2016 and documented autochthonous transmission in May 2016. As of September 2, 2016, 5299 suspected and 92 confirmed Zika infections and as of September 5, 111 suspected GBS cases were reported (6).

Guillain-Barre syndrome cases were anecdotally infrequent in Jamaica. A young female with flaccid quadriparesis and bulbar weakness with the acute motor-sensory axonal GBS variant, occurring three weeks post a gastrointestinal illness and who later died from complications has been described (7). Guillain-Barre syndrome is an acute inflammatory polyradiculoneuropathy commonly occurring two to three weeks after an infection as a result of antibodies directed at the infectious agent cross-reacting with peripheral nerve epitopes (8). Guillain-Barre syndrome classically presents as rapidly ascending areflexic limb weakness with mild sensory changes and occasional bulbar and respiratory muscle weakness though there are several described variants. Clinical diagnosis is supported by cyto-albumin dissociation characterized by an elevated cerebrospinal fluid (CSF) protein in the absence of an elevated cell count greater than 50 cells per microlitre and neurophysiology which can further classify GBS as a demyelinating or an axonal polyneuropathy (9). Immunoglobulin (IVIg) and plasma exchange are equally effective and either are recommended for non-ambulatory patients and progressively worsening ambulatory patients who are within 28 days of neuropathic onset $(10,11)$. At six and 12 months about 80 and $84 \%$ of persons are ambulatory (12).
Other reported neurological syndromes include transverse myelitis (TM), meningoencephalitis (ME), encephalitis (EN) and acute disseminated encephalomyelitis [ADEM] (13-16), therefore, a broad operational definition is warranted to describe Zika outbreak associated neurological syndromes. The demographic, clinical and laboratory features of Zika outbreak associated neurological syndromes at the KPH and the early experience of their treatment and outcomes are described.

\section{SUBJECTS AND METHODS}

Men and women aged 12 years and over admitted to Internal Medicine and/or Neurology services between April to September 2016 at the KPH and meeting the criteria for a Zika outbreak associated neurological syndrome were identified for retrospective medical record review.

\section{Operational definitions}

Zika outbreak associated neurological syndrome: neurological syndrome characterized by acute/sub-acute monophasic bilateral areflexic/hyporeflexic limb weakness and/or sensory impairment with/without cranial nerve, meningeal, myelopathic or encephalopathic abnormalities, with/without antecedent viral symptoms, without another more reasonable explanation during the recent Zika outbreak.

Guillain-Barre syndrome or GBS: acute or sub-acute monophasic autoimmune polyradiculoneuropathy meeting the Brighton Criteria (17).

Suspected Zika virus infection (and Zika symptoms): rash or elevated body temperature $>37.2^{\circ} \mathrm{C}$ with one or more of the following symptoms (not explained by other medical conditions): arthralgia, myalgia, non-purulent conjunctivitis or conjunctival hyperaemia, headache or malaise; in someone who resides in or has visited epidemic or endemic areas within two weeks prior to the onset of symptoms; Post-viral neurological syndromes and autoimmune syndromes are to be considered suspected cases of Zika virus infection.

Confirmed Zika virus infection: A suspected case with laboratory positive result for the specific detection of Zika virus.

\section{Measurements}

Parameters assessed include age, gender, time to neuropathic symptoms from viral symptom onset, time to nadir of neurological symptoms, viral symptoms, neurological signs, CSF 
analysis, neurophysiology, neurological syndrome classification, serology and real-time-polymerase chain reaction (RT-PCR) for Zika, Dengue and Chikungunya, brain and spinal cord magnetic resonance imaging (MRI), respiratory failure, Intensive Care Unit (ICU) admission, Immunoglobulin therapy and outcomes such as venous thromboembolism and death. Neurological syndrome classification was based on clinical features, brain and spinal cord MRI, CSF analysis and neurophysiology.

\section{Statistical analyses}

The SPSS software v. 22 was used to determine descriptive statistics such as means and proportions for demographic, clinical and laboratory features. The Chi-squared test was used to assess the association between exposure variables, for example dysautonomia and risk for an adverse outcome such as death or ICU admission.

\section{RESULTS}

Thirty-five met the criteria for inclusion and 25 medical records were reviewed. Frequency of specific neurological syndromes and positive viral serology are outlined in Table 1.

Table 1: Zika outbreak associated neurological syndromes

\begin{tabular}{lc}
\hline Variable & Frequency \\
\hline Neurological syndrome & 25 \\
Guillian-Barre syndrome & 21 \\
• GBS Brighton Level 1 & 3 \\
• GBS Brighton Level 2 & 11 \\
Transverse myelitis & 7 \\
Meningoencephalitis & 1 \\
Acute disseminated encephalomyelitis & 2 \\
Virus positive serology (IgM) & 1 \\
Zika Guillian-Barre syndrome & 2 \\
Zika Meningoen & 1 \\
Dengue Guillian-Barre syndrome & 2 \\
Dengue and Chikungunya Guillian-Barre syndrome & 1 \\
\hline
\end{tabular}

GBS $=$ Guillian-Brighton syndrome; $\mathrm{TM}=$ transverse myelitis; $\mathrm{ME}=$ Meningoencephalitis, $\mathrm{ADEM}=$ acute disseminated encephalomyelitis; Igm = immunoglobulin

Men and women were affected almost equally (13 vs 12); on average, men were older than women (46.6 vs 38.8 years). Seventeen of 21 GBS cases reported symptoms consistent with Zika infection, with headache (9), vomiting (9), rash (8), fever (6) and conjunctivitis (4) being the most common despite only two with positive Zika IgM serology (Table 1) and no Zika positive RT-PCR.

Guillain-Barre syndrome occurred on average four days from onset of viral symptoms and time to clinical nadir averaged 7.15 days from neuropathic onset. Eight patients had a para-infectious onset with neurological symptoms on day 1 of viral symptoms. Clinical features of GBS were: flaccid quadriparesis or quadriplegia (76\%), dysphagia (62\%), dysphonia (67\%), bilateral facial weakness (71\%) and flaccid paraparesis or paraplegia (14\%). The distribution of weakness was proximal more than distal in most patients $(81 \%)$ with significant vibratory impairment observed to the knees and above, often to the high thoracic level (86\%). Eight per cent had pure sensory symptoms with ataxia. Sixty-seven per cent had features of dysautonomia characterized by persistent tachycardia, new or worsening hypertension and blood pressure lability with a trend towards significance for death $(p=0.074)$.

Systematic clinical examination for mental status changes, meningeal signs and a sensory level corroborated by demyelination on brain and/or spinal cord MRI or, as appropriate, evidence of a CSF pleiocytosis identified those cases of transverse myelitis (TM), meningoencephalitis (ME) and acute disseminated encephalomyelitis (ADEM). The four cases thus identified also had initial and persistent clinical features of a flaccid quadriparesis and cranial neuropathies.

Nerve conduction studies in four GBS patients all showed an acute demyelinating neuropathy. Eighty-seven per cent of 15 lumbar punctures demonstrated cyto-albumin dissociation. Despite initial CSF pleiocytosis for patients with $\mathrm{ME}$ and ADEM, gram stain and cultures were negative.

Nine GBS patients ( 5 men with average age 53 years; 4 women with average age 45.8 years), 1 of 2 with ME and both cases of TM and ADEM had respiratory muscle failure and were admitted to the ICU for mechanical ventilation. Twentythree out of 25 patients received IVIg; two with purely sensory GBS improved and were ambulatory at discharge without IVIg. Patients with TM and ADEM were also treated with intravenous corticosteroids and empirical anti-meningitic doses of antibiotics were given to both patients with ME. All had physiotherapy, nutritional support, venous thromboembolism prophylaxis and psychosocial support. Four patients died (three men whose ages were 61, 64 and 78 years).

\section{DISCUSSION}

Zika outbreak neurological syndromes were commonly associated with antecedent viral symptoms but only 2 had evidence of acute Zika infection. Potential reasons for this include inadequate or late sample collection, poor sample handling as well as the narrowness of the window for identifying the virus in body fluids. Still possible is that not all are Zika-related and may be due to other viruses, including influenza especially (H1N1), Chikungunya and Dengue which can produce similar neurological syndromes (18). 2 GBS patients were positive for acute Dengue IgM and another had positive IgM for Dengue and Chikungunya.

Interesting to note are the mixed neurological pictures seen in a minority of the patients with features typical of GBS and another neurological syndrome such as TM or ME. One of two patients with ME had positive Zika IgM.

The association between dysautonomia and risk of death $(p=0.074)$ will require further data collection or data pooling to confirm an association.

In this epidemic, cases of GBS had an increased tempo from onset to nadir, more frequent bulbar and respiratory 
muscle failure requiring ICU admission and increased mortality, $16 \%$ vs $4 \%$ for classic post-infectious GBS (12). The cooccurrence of acute viral symptoms with the evolving neurological syndrome suggest that mechanisms other than post-infectious auto-immune mechanisms (8) including direct viral toxicity may contribute to this unique temporal relationship (5).

Men with GBS were older than average and appeared to have greater mortality (three of four deaths were men over age 60 years). Although preliminary, age and male gender may be important risk factors for more severe outcomes. Viral persistence in seminal fluid may conceivably place older men at greater risk of more severe disease (19).

Conversely, two patients with pure sensory GBS did not need IVIg for recovery. Anecdotal reports from outpatient practices suggest that the sensory variant, typically manifested as paraesthesia and/or burning/cold dysaesthesia may be more common than clinically reported.

Late identification of neurological complications and consequent delays in initiating disease-modifying treatment (IVIg), though not specifically described here, along with a potentially uniquely more severe phenotype of GBS and other Zika outbreak associated neurological syndromes may have accounted for the greater overall morbidity and mortality in our patients. Knowledge of these neurological complications, early syndromic classification, in particular of the most common neurological complication, GBS, with early initiation of IVIg treatment may alter the clinical trajectory of these patients, reducing their maximum deficits and need for ICU care and thus, may reduce overall healthcare costs.

\section{CONCLUSION}

The Zika outbreak has brought a range of acute neurological complications many of which are usually rare and/or unusual in clinical phenotype. As the epidemic evolves, final definitive ascertainment of the overall risk of GBS or other neurological complications will be clearer when the entire island has eventually been exposed and with systematic research. Meanwhile, we hope that sharing our early clinical experiences will augment early diagnosis, reduce treatment delays and reduce morbidity and mortality of Zika outbreak associated neurological syndromes in Jamaica and beyond our shores.

\section{ACKNOWLEDGEMENTS}

The Kingston Public Hospital Senior Medical Officer (Dr Natalie Whylie), Health Records Manager (Mrs Jacqueline McDonald-Douglas) and Neurology Resident (Dr Stephanie Williams) for assistance in data collection.

\section{AUTHORS' NOTE}

M Williams and A Ali performed data analysis, writing, critical appraisal and together approved final version of paper. The authors declare they have no conflicts of interest.

\section{REFERENCES}

1. World Health Organization. Zika situation report: Neurological syndrome and congenital anomalies. Available from: www.who.int/emergencies/ zika-virus/situation-report/5-february-2016/en.

2. Wikan N, Smith DR. Zika virus: history of a newly emerging arbovirus. Lancet Infect Dis 2016; 16: e119-e126. DOI: https://dx.doi.org/10.1016/ S1473-3099 (16)30010-X.

3. Kindhauser MK, Allen T, Frank V, Santhana RS, Dye C. Zika: the origin and spread of a mosquito-borne virus [Submitted]. Bull World Health Organ. E-pub: 2016 Feb 9. DOI: http://dx.doi.org/10.2471/BLT. 16.171082.

4. Duffy MR, Chen T, Hancock WT, Powers AM, Kool JL, Lanciotti RS et al. Zika virus outbreak on Yap Island, Federated States of Micronesia. New Engl J Med 2009; 360: 2536-43. Available from: www.nejm.org/ doi/full/10.1056/NEJMoa0805715.

5. Cao-Lormeau VM, Blake A, Mons S, Lastere S, Roche C, Ghawche F et al. Guillain-Barre Syndrome outbreak associated with Zika Virus infection in French Polynesia: a case control study. Lancet 2016; 387: 1531 9. DOI: http://dx.doi.org/10.1016/S0140-6736 (16) 00562-6.

6. Ministry of Health, Jamaica. Jamaica Confirms First Case of the Zika Virus. Available from: http://moh.gov.jm/?s=zika+first+case+jamaica.

7. Fletcher-Peddie K, Alfred R, Penn-Brown K, Gayle F, Gilbert DT, Elliot V, Ferguson TS. Guillain-Barré syndrome and its variants: a case of acute motor-sensory axonal neuropathy in Jamaica. West Indian Med J 2013; 62: 658-66. DOI:10.7727/wimj.2013.039.

8. Hafer-Macko CE, Sheikh KA, Li CY, Ho TW, Cornblath DR, McKhann GM et al. Immune attack on the Schwann cell surface in acute inflammatory demyelinating polyneuropathy. Ann Neurol 1996; 39: 625-35. Available from: www.ncbi.nlm.nih.gov/pubmed/8619548.

9. Ropper AH. The Guillain-Barré syndrome. N Engl J Med 1992; 326: 1130-36. Available from: https://dx.doi.org/10.1056/NEJM 199204233261706.

10. Hughes RA, Swan AV, van Doorn PA. Intravenous immunoglobulin for Guillain-Barré syndrome. Cochrane Database Syst Rev 2014; 9: CD002063. Available from: www.ncbi.nlm.nih.gov/pubmed/25238327.

11. Raphaël JC, Chevret S, Hughes RA, Annane D. Plasma exchange for Guillain-Barré syndrome. Cochrane Database Syst Rev 2012; 7: CD001798. Available from: www.ncbi.nlm.nih.gov/pubmed/22786475.

12. Rajabally YA, Uncini A. Outcome and its predictors in Guillain-Barre syndrome. J Neurol Neurosurg Psychiatry 2012; 83: 711-18. DOI: www.ncbi.nlm.nih.gov/pubmed/22566597.

13. Ferreira MLB. Neurologic Manifestations of Arboviruses in the Epidemic in Pernambuco, Brazil. American Academy of Neurology: Vancouver, Canada. Available from: https://www.aan.com/PressRoom/Home/GetDigitalAsset/12033.

14. Carteaux G, Maquart M, Bedet A, de Broucker T, Brun-Buisson C, Leparc-Goffart I et al. Zika virus associated with meningoencephalitis. N Engl J Med 2016; 374: 1595-96. DOI: 10.1056/NEJMc1602964.

15. Mecharles S, Herrmann C, Poullain P, Tran TH, Deschams N, Mathon G et al. Acute myelitis due to Zika virus infection. The Lancet; 387 (10026): 1481. Available from: http://dx.doi.org/10.1016/S0140-6736(16)006449.

16. Soares CN, Brasil P, Carrera RM, Sequeira P, de Filippis AB, Borges VA et al. Fatal encephalitis associated with Zika virus infection in an adult. J Clin Virol 2016; 83: 63-65. DOI: http://dx.doi.org/10.1016/j.jcv. 2016.08.297.

17. Sejvar JJ, Kohl KS, Gidudu J, Amato A, Bakshi N, Baxter R et al. Guillain-Barré syndrome and Fisher syndrome: case definitions and guidelines for collection, analysis, and presentation of immunization safety data. Vaccine 2011; 3: 599-612. Available from: https://www.ncbi.nlm. nih.gov/pubmed/20600491.

18. Ferreira ML, Cavalcanti CG, Coelho CA, Mesquita SD. Neurological manifestations of dengue: study of 41 cases. Arq Neuropsiquiatr 2005; 63: 488-93. Available from: http://dx.doi.org/10.1590/S0004-282 X2005000300023.

19. Harrower J, Kiedrzynski T, Baker S, Upton A, Rahnama F, Sherwood J et al. Sexual transmission of Zika virus and persistence in semen, New Zealand, 2016. Emerg Infect Dis 2016; 22: 1855-7. DOI: http:// dx.doi.org/10.3201/eid2210.160951. 